\title{
Station camps: legislation, labour relations and rations on pastoral leases in the Kimberley region, Western Australia
}

\author{
Pamela A Smith
}

The Kimberley region in north Western Australia (Figure 1) was one of the most recent regions in Australia to be colonised. The first pastoralists came to this region overland from Queensland in the mid-1880s and their first encounters with the Aboriginal population were in the East Kimberley (Clement 1987a; 1987b; Ross and Bray 1989; Smith this issue). There is no doubt that there was an expectation that people from the many Aboriginal tribal groups would provide cheap labour on the new cattle stations. Forrest, who explored the region in 1879-80 and who had forwarded favourable reports regarding the suitability of the country for cattle, had specifically noted that the large number of Aborigines in the region would allay concerns about the availability of cheap labour (Bolton 1958: 28).

From the Aboriginal perspective, the invasion and occupation of their traditional country by the pastoralists at the end of the nineteenth century marked the commencement of the transition from their traditional hunter-gatherer lifestyle to a less mobile lifestyle in the station camps on cattle stations, and was the first of several significant social and demographic changes which were to occur over the next century. For most Aboriginal people living in this region, the period between the $1880 \mathrm{~s}$ and the $1920 \mathrm{~s}$ must have been a time of fear and chaos. It was not, however, a period of complete dispossession, as most continued to share their land with the pastoralists until the 1970s (interviews 2, 23 and 27).

Historical documents, archival records and recorded interviews with Aboriginal people are analysed in this paper in order to better understand the dynamics between these two groups in the post-invasion period and the history of the pastoral industry in the Kimberley region. The introduction of legislation to control the Aboriginal population between 1880 and the 1920s, the early history of the ration system and the methods used to control them and to bring them under surveillance are documented in the first part of this paper.

By the 1920s life on the cattle stations had evolved an annual routine and the Aboriginal population had been incorporated into the hierarchical structure of the pastoral industry. The second part of the paper outlines changes in the legislation controlling 
Aboriginal labour on cattle stations from the 1920 s to the 1970 s, and explores the socioeconomic contexts of the ration system of that period.

\section{0-1920s - control by legislation and rations}

That very cheap labour would facilitate the development of economic enterprise had been fundamental to the colonial culture of all European colonies during the 17th, 18th and 19th centuries. The only cost of this labour was the price of food and clothing. Little distinguished the manner of the employment except the names given to the labourers: convicts, slaves, natives. Early free settlers in most Australian states had access to convicts and in Queensland the Kanakas, slaves from Melanesia, worked the sugar plantations. In those areas where there were no convicts (South Australia, Northern Territory and northern Western Australia) many colonists pressed Aborigines into service. In the south of Western Australia free convict labour had been used by the settlers to establish rural and urban enterprises; for this reason the Western Australian government continued to demand convicts from Britain until well after other colonies had ceased transportation. The use of convict labour in Western Australia ended in 1867 (James 1979: 19).

The use of convict labour in Western Australia had, however, been prohibited above the twenty-sixth parallel and at the time colonists were speculating about the suitability of northern Australia for pastoral enterprise, the availability of cheap labour

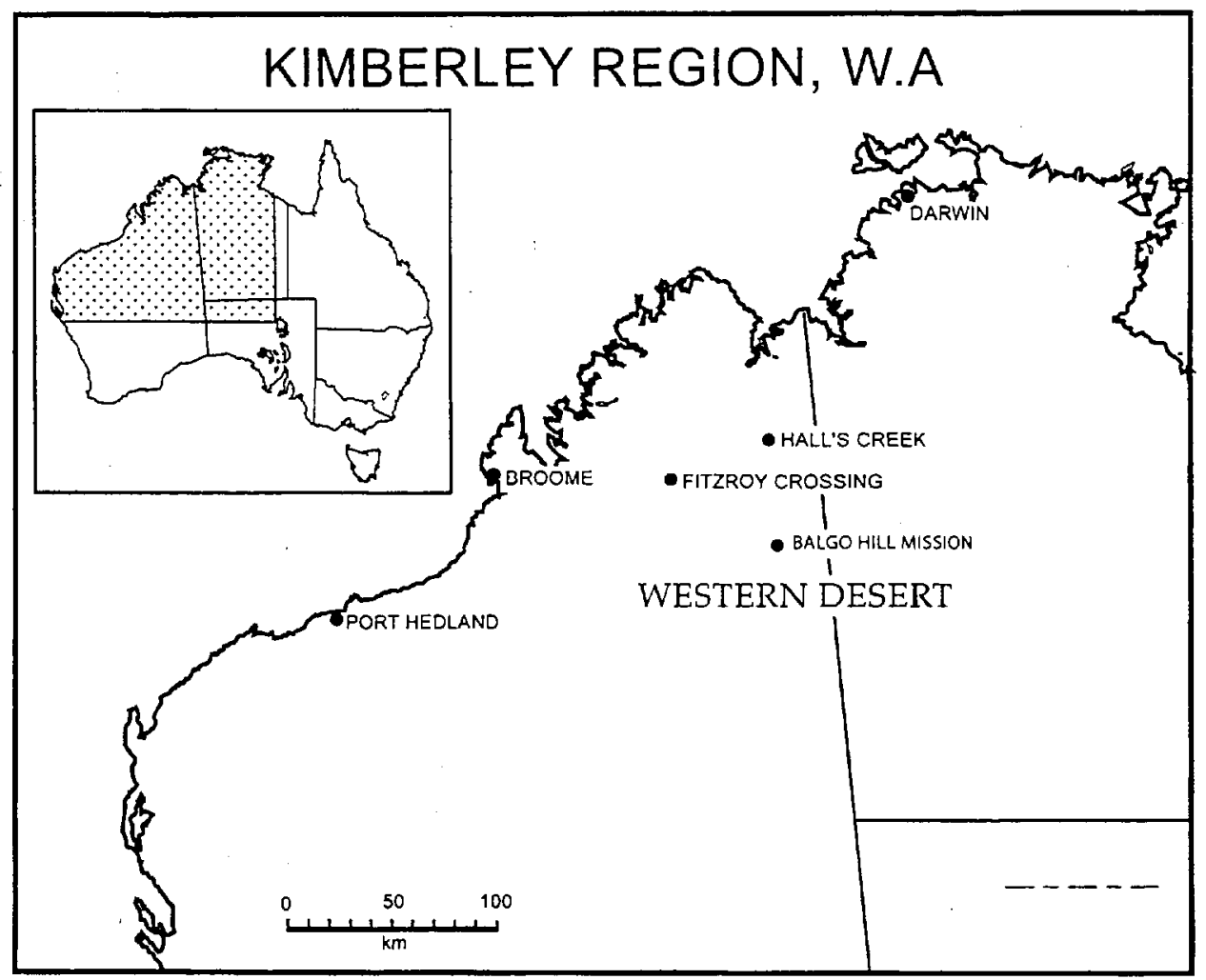

Figure 1. Map of northwest Australia, showing the Kimberley region. 
was a part of their deliberations. Alexander Forrest, well before his Kimberley expedition, observed that:

Queensland (was) cultivating tropical products with the aid of the unhappy Kanakas from Pacific Islands; why should not Western Australia import Hindus and Chinese? If, indeed, there were not Aborigines to train as cheap labour, perhaps an indenture system could be devised for the frugaI Asiatic (quoted in Bolton 1958: 28).

Indentured Asians were used as cheap labour by the pearling industry along the Kimberley coast, but this system was not introduced to provide labour for land-based commercial activities, and it was soon apparent that cheap Aboriginal labour was essential to the success of the pastoral industry in the Kimberley region. ${ }^{1}$

\section{Legislation}

The history of these first years of the pastoral industry from the pastoralists' perspective is thoroughly documented through the legislation, commissions and reports of the period. Arranged chronologically these merge into a one-sided account of history. New laws were defined by and for the colonists to serve their interests, and they reflect the prevailing political and social climate. The legislation gave the pastoralists and the police extensive powers to control and restrict the lives of the Aboriginal people. The police, paradoxically empowered under the 1886 Aborigines Protection Act as 'honorary protectors' of the Aborigines, were paid an allowance of $2 \mathrm{~s} .5 \mathrm{~d}$. 'per knob' per day for all natives arrested as suspects and as witnesses to raids on stock (Durack 1967: 370). This made it profitable for the police to arrest as many as possible and it was those living outside the emerging authority of the pastoral industry who were arrested.

Chained together neck to neck, wrist to wrist, the long lines of prisoners, men, women and children wound their way over the bush tracks to receive sentence in Wyndham, Derby or Halls Creek ... acquittals were nil. Brief scattered entries reveal Father's growing sense of discomfiture at the situation: 'Am disgusted at the spectacle of a party of niggers on the road with police, the chains in many instances much too short from neck to neck, chafing and pulling as they move along and all appearing half starved' (Durack 1967: 370).

The inquiries, reports and legislation which affected the lives of Aboriginal people during the first two decades of pastoral expansion are summarised in Table 1. A notable omission is the Australian Constitution, 1901, which failed to include any reference to Indigenous Australians. Each report or new legislation sought to control the movement and activities of Aboriginal people, to make them dependent, or to improve the surveillance of their movements and activities.

The Roth Royal Commission (Royal Commission, State of Western Australia 1905) was called in response to complaints about the treatment of Aborigines less than 20 years after the first pastoralists had colonised the Kimberley. Because of the broad scope of the inquiry and the large size of Western Australia, the Royal Commission was confined to the employment and treatment of Aboriginal people living in missions in all of

1. There was a system whereby an Aborigine could be employed by contract or could be indentured as an apprentice; both methods were detailed in Commissioner Roth's report (Royal Commission, State of Western Australia 1905: 7-9). 
Western Australia and to Aboriginal labour in the pearling and pastoral industries in the Kimberley region. The report made many recommendations, most of which were relevant to labour relations, living conditions, the establishment of reserves and relief for dependent Aborigines, the roles of the police, protectors and employers and the treatment of prisoners and prison conditions. Commissioner Roth observed that:

If the natives continue to be dispossessed of the country upon which they are dependent for their food and water supplies, by their lands being rented for grazing rights at a nominal figure - lands from which the lessees naturally desire to drive them - bloodshed and retribution will be certain to ensue.

Royal Commission, State of Western Australia 1905: 28

The passing of the Native Administration Act (1905-47) and the Aborigines Protection Act (1905) in response to Commissioner Roth's report put in place the legislative controls which enabled the surveillance and control of the Aboriginal population by agents of the government for the next fifty years.

The Native Administration Act (1905-47) sought to regulate Aboriginal people more than any other legislation in Western Australia. Through 70 provisions it imposed prohibitions, restrictions and limitations which robbed them of personal freedom and denied them opportunities of citizenship. Notable examples of these provisions are:

- The Commissioner was appointed legal guardian of every Aboriginal child until the age of 21 and was empowered to direct what person should have custody of the child.

- The Minister was empowered to issue a warrant providing for the arrest of an Aboriginal and his confinement for as long as he deemed fit. No judicial process was involved and there was no provision for appeal. (This was used for the separation of children from their parents and also the removal of whole families to institutions.)

- It was an offence for an Aboriginal to move from north of the 26th paralleI latitude without a permit from the Minister.

- It was an offence for Aborigines to leave their employment (15 sections regulated the employment of Aborigines).

- Police officers could order Aborigines out of towns and parts of towns and cities could be declared prohibiced areas for Aborigines.

- It was an offence for a female Aborigine to be within two miles of the mouth of a creek or inlet between sunset and sunrise.

- An Aborigine could be banished from his country for cattle killing.

- An adult Aborigine had to obtain the Commission's consent to marry. (Royal Commission, State of Western Australia 1974)

The Aborigines Protection Act (1905) ensured that Aborigines in the Kimberley remained on the stations. They were not permitted below the 26 th parallel without a permit from the Minister and it was an offence to move from the station where they were settled, a regulation that was enforced until the $1960 \mathrm{~s}^{2}$ (see Andrews 1996: 148).

\section{The means of control}

The question of why the Aboriginal people moved to the station camps is not easily answered. The pastoralists colonised the land and they controlled who passed through 


\section{Table 1: Legislative controls relating to Aboriginal people in the Kimberley,} WA, 1860-1906*

\begin{tabular}{|c|c|c|}
\hline Date & Name & Discussion \\
\hline 1880 & Act 44 Victoria no. 9 & To prohibit the sale of alcohol to Aboriginal people. \\
\hline 1882 & Fairbaim Report & $\begin{array}{l}\text { To investigate allegations of Aboriginal hostilities } \\
\text { toward pastoralists - Murchison/ Gascoyne region. }\end{array}$ \\
\hline 1884 & $\begin{array}{l}\text { Forrest Commission - A } \\
\text { Royal Commission }\end{array}$ & $\begin{array}{l}\text { Established in response to requests by pastoralists/set- } \\
\text { tlers for government assistance with the 'Aboriginal } \\
\text { problem'. }\end{array}$ \\
\hline 1886 & Aborigines Protection Act & $\begin{array}{l}\text { Establishment of Aborigines Protection Board. Consti- } \\
\text { tuted to provide food and clothing to destitute Aborigi- } \\
\text { nes, education for children. In fact, it greatly extended } \\
\text { government powers to regulate and control Aboriginal } \\
\text { people. }\end{array}$ \\
\hline 1890 & Constitution Act & $\begin{array}{l}\text { Provided funds to Aborigines Board for the welfare of } \\
\text { Aboriginal people. }\end{array}$ \\
\hline 1890 & Act 52 Victoria no. 24 & Provided Crown Lands for use by Aboriginal people. \\
\hline 1892 & $\begin{array}{l}\text { Amending Act } 55 \text { Victoria } \\
\text { no. } 18\end{array}$ & $\begin{array}{l}\text { Passed to authorise the whipping of Aboriginal offend- } \\
\text { ers. }\end{array}$ \\
\hline 1893 & Aborigines Offenders Act & $\begin{array}{l}\text { Amended to provide for increased punishments for } \\
\text { Aboriginal offenders. }\end{array}$ \\
\hline 1898 & $\begin{array}{l}\text { Aborigines Department } \\
\text { established }\end{array}$ & $\begin{array}{l}\text { Abolition of Aborigines Protection Board, Chief Protec- } \\
\text { tor of Aborigines now responsible for Aboriginal affairs. }\end{array}$ \\
\hline $1904 / 5$ & $\begin{array}{l}\text { Commissioner Roth's Royal } \\
\text { Commission }\end{array}$ & $\begin{array}{l}\text { Inquired into administration of the Aborigines Depart- } \\
\text { ment, employment of Aborigines, Aboriginal police sys- } \\
\text { tem, treatment of Aboriginal prisoners and distribution } \\
\text { of relief. Recommended the protection of Aborigines by } \\
\text { strict controls. }\end{array}$ \\
\hline 1905 & $\begin{array}{l}\text { Aborigines Protection Act } \\
(1905) \\
\text { Native Administration Act } \\
\text { (1905) }\end{array}$ & $\begin{array}{l}\text { Chief Protector given statutory powers to enact recom- } \\
\text { mendations of the Royal Commission. Power to protect } \\
\text { and control, to act as legal guardian of Aboriginal chil- } \\
\text { dren with authority to remove them from their parents. } \\
\text { Introduction of many restrictive measures. }\end{array}$ \\
\hline
\end{tabular}

it; the traditional owners became trespassers and were persecuted when living in the bush and were subjugated by arrests and massacres (see Durack 1967: 370). Those who stayed in the bush, the myalls, were considered a nuisance; in order to pass through their own country they had to develop new strategies to avoid meeting white people

2. Daisy Andrews recounts: 'I was born in Cherrabun. That is my country because I was born there. My mother and father liked Cherrabun but my father never got used to working on a station, and he used to go away from there, you know, run away and leave the job. Then a policeman came and picked up father from Cherrabun and took us to the old police station at Fitzroy Crossing' (Andrews 1996: 148). 
and to stay alive. The growing body of evidence for the number of Aboriginal people maimed or killed during this period makes it increasingly doubtful that the pre-invasion population numbers can ever be estimated.

Using the colonization of the southeast Kimberley as an example, oral histories leave no doubt that the Nyininy/Djaru competed with the cattle for water and were hunted and maimed or killed to discourage them from using the waterholes (Taylor 1988:39; interview 3; K Doohan, pers. comm.). They were forced to live on the run, move to the rugged fringes of the Tanami Desert, or settle at the station camps and be incorporated into the pastoral industry. Micha recorded two methods used to ensure that captured Aborigines stayed on the stations:

Older Aborigines today still remember the time when the hard soles of their feet were lacerated by files, of the sort which are used to work horse's hoofs, in order to prevent them from running away, and still today one may see e.g. iron balls, to which black women were chained - for the disposal of the mostly single station managers and as hostages for their working but striving-away husbands.

Micha 1961: $67^{3}$

Commissioner Roth, in his report of the 1905 Royal Commission on the Condition of Natives, referred to an additional method of obtaining labour whilst at the same time enticing people to live closer to the station - the stealing of strong healthy children from their families still living a traditional lifestyle in order to have them live in the stock camps with the 'stock boys' already recruited. Commissioner Roth reported that 'pastoralists have taken most of the native boys from the tribes; the blacks come in from the bush to get tobacco and food from the boys working on the stations' and this is when their children were taken (Royal Commission, State of Western Australia 1905).

The introduction of rations to entice and coerce Aboriginal people to live in permanent camps on the stations commenced within ten years of colonisation. ${ }^{4}$ In 1896 Flora Valley Station was the first Kimberley cattle station recorded as having supplied rations to the Aborigines (Ross 1987: 13). They were followed by Ord River Station in 1905, although according to Ross, with an element of coercion of the management (Ross 1987: 13). In 1908, in a bid to resolve the tensions between Aborigines and pastoralists, the Chief Protector of Aborigines asked station owners whether they were prepared to kill enough beef to satisfy the needs of Aborigines in the adjacent country and if so, would they require compensation. Ross concluded from this that the practice of giving beef to Aborigines was begun in order to discourage cattle spearing (Ross 1987: 15).

\section{Labour, rations and dependency}

Viewed from within the political milieu of the time, it is likely that there were at least two reasons for the introduction of rations, both of them economic. The first was to stop the spearing of cattle, many of which were valuable breeding stock, and the second was to gain control of a cheap labour force. The spearing of cattle was certainly a serious issue as stock losses were high, but the question of the availability of cheap labour was the more pressing of the two issues. As previously mentioned, there is no doubt that the

3. Translated from German into English by Micha.

4. A history of the ration system in central and northern Australia at an earlier time is given by Rowse (1998: 13-48). 
pastoralists came with an expectation of using Aboriginal labour and that this was a more urgent issue in the 1890 s than in the late $1870 \mathrm{~s}$ when it was raised by Forrest (cf. Bolton 1958: 28). A prolonged drought during the 1890s, the high cost of taking cattle long distances to markets, the intense political battles over quarantine regulations, and new cattle diseases (Durack 1967:379-81) meant that the earlier promise of great wealth was less likely to be realised.

Knowledge about the pastoralists, their cattle, their tobacco and the flour which didn't need to be ground, spread quickly. In addition to rations provided to 'workers', pastoralists made small parcels of ration foods available to all who called at the stations. At a slightly later time, elderly Aboriginal people in an adjacent region recalled trading 'thumb-sized packages of tea and sugar as well as steel tools from the Kimberleys in the mid 1930s' (Cane 1990: 13); and an elderly woman recalled a story of how her family had called at Sturt Creek station (probably in the late 1920 s or early 1930s) and had been given rations for the first time. Not knowing what to do with them, they had buried them for fear of the kartiya's $s^{5}$ magic (interview 12).

The ration was a measured portion of food handed out to Aboriginal employees and their dependents from the station store. It comprised a quantity of flour ${ }^{6}$, tea and sugar together with a stick of tobacco, called 'nigi-nigi'. In addition, salt beef and damper or bread may have been given to those who were working at the station homestead during the day. Those who were not 'workers' who were living in the camp would be fortunate to receive the hoofs, bones and intestines of a 'killer' (McPherson 1995; K Akerman pers. comm.; interview 9), although this did depend on the generosity of the current station owners and managers. In these early years staple foods were often common to both Aboriginal and non-Aboriginal station workers, particularly where there was no access to a homestead garden. As a generalisation, the differences between the ration provided to the Aboriginal workers and the diet provided to the non-Aboriginal station employees were the quality and quantity of the beef provided, the quantities of the flour, tea and sugar provided, and the variety of foods used in addition to the staples. For example, dried foods such as rice and dried vegetables such as blue boiler peas were added to stews.

These supplies were brought to the stations twice a year from the ports of Wyndham and Derby. They were brought by the Gan - the Afghans and their train of camels - who brought supplies to the remote areas of northern and central Australia. Terry (1927: 159) provides a unique description of the arrival of one camel train at Gordon Downs station during his stay in the mid-1920s:

Towards sundown that day a picturesque sight stalked to the homestead. It was a train of pack camels in the charge of Afghan camel men, arriving with stores from Wyndham. In a long winding string, tied nose to tail, they appeared out of the Bush, glowing as if on fire in the setting sun. In fact it seemed they were really walking straight out of the sun ... Slowly with dignified mien, the train ceased its paces by the homestead. Quietly the Afghan camel men walked down the train, catching nose lines, murmuring the inevitable 'Whoosta'. Tired beasts sank to

5. 'Kartiya' is the word generally used for a white person in the east Kimberley.

6. The measure for flour was reported as being the depth measured from the fist to the elbow in a calico flour bag. This was for one family for one week. 
earth, chewing the cud leisurely, gazing in supercilious disdain on all around...Packs dropped to the ground; camels rose up, free to roam the night through. They marched away a step - a pause - a step - a pause, without hurry or fuss, leaving two lines of merchandise near discarded pack saddles as testimony to their labours ended for a while.

Again using the southeast Kimberley as an example, supplies were taken by camel train as far as the larger stations such as Gordon Downs and Sturt Creek and smaller stations further to the south had to collect their supplies from the nearest of the larger stations. Stories of family trips by wagon to collect stores were recalled (interview 6), whilst others told of their people being forced to carry bags of salt and flour long distances to remote stations in the time before the camels came. Occasions have been recorded when they were whipped if they became too tired and they were chained to prevent them from running away (K Doohan pers. comm.).

Whether easy access to food and tobacco, curiosity or just fear of living in the bush account for why people moved to the station camps, most Aboriginal people did move closer to the station camps in the first two to three decades following colonisation. ${ }^{7}$ The pastoralists, sure of their own racial superiority, selected their labour force from the strong and healthy, and ignored the health and squalid living conditions of the less able-bodied (generally the elderly) living in the station camps. This attitude is evident in a photograph taken by Terry whilst travelling through the Kimberley region (Terry 1925: opp. page 226).

The pastoralists perceived the failure of the Aboriginal population to develop the economic potential of the land as a moral failure. In fact, traditional methods of harvesting, the storage of surplus dried fruit and seed and the concern for the seasonal regeneration of all flora and fauna expressed through ritual and in species management were largely unnoticed by the pastoralists. The impact of pastoralism on the traditional social organisation of the Aboriginal people was devastating and they were incorporated into the lowest rung of the pastoral economy. The demographic structure of traditional society had already been greatly altered through the loss of many young men from the frontier violence, through the many deaths from introduced infectious diseases, particularly of elders and children, and through a continuing high infant mortality rate from diarrhoeal disease resulting from the appalling living conditions and lack of ablution facilities in the station camps (Saggers and Gray 1991: 67).

Settlement living, coupled with the conditions of employment and what it brought in terms of food became linked with increasing malnutrition and high infant mortality and, in turn, with a diminution of traditional activity. Any desire to move away from the base camp was correspondingly lessened; and for good workers it was virtually an impossibility, except at short periods of limited walkabout. Family life was being upset. This was not just in terms of children being produced, or not being produced, but in terms of the revamping of male-female

7. Terry and a companion passed through the Sturt Creek area in 1925. Their vehicle broke down close to Mt Wittenooom and they had to walk for several days and almost lost their lives. Although this is an area where there are large traditional camp sites along the Sturt Creek, Terry did not encounter any Aboriginal people living in the area (Terry 1925: 244-66). He did, however, comment on the large Aboriginal camp at Gordon Downs when he arrived there (Terry 1925: 267). Although this is very circumstantial evidence, it does support the argument that most Jaru had moved to the station camps by the 1920 s. 
roles - in relation to marital responsibilities, both economically and emotionally and in the claims of Europeans for sexual access to females married or unmarried, children or adults (Berndt and Berndt 1987: 275).

Traditional relationships between men and women were also altered. Station managers and stockmen often availed themselves of Aboriginal women for sexual satisfaction and more permanent liaisons were frequent. Aboriginal men were rendered powerless in these relationships because of their inability to intervene. The relationships between men and women were also altered by the increase in opportunities for women to extend their range of social interaction beyond the camp (Bell 1983). Many Aboriginal people found that to be in a close and dependent relationship with the pastoralists was safer than to be free but vulnerable in the bush (Kolig 1987: 27).

Others chose to remain in the bush and some stations became known as 'refuges'. Lewis Creek Station and Slatey Creek Station, marginal pastoral leases in the northern Tanami Desert, were reputed to have been such 'safe' areas (K. Doohan pers. comm.). Tom Bradshaw was at Slatey Creek and Jack Skeen and Dave Piggley were at Lewis Creek; all were married to Aboriginal women. Following the Sturt Creek massacre in the 1920s many people from Sturt Creek took refuge at Lewis Creek Station and Piggley is reported to have carried a pair of pistols which he used to threatened white men who came looking for Aboriginal people. Mostly, however, it was the elderly and children who lived there, while the young men and women worked for rations on adjacent stations (interview 6).

There were also some positive outcomes as the new social order gradually asserted itself. Working with cattle replaced hunting as the activity through which men acquired prestige. This occurred, however, within the hierarchical structure of station economies and was often external to traditional relationships.

Aboriginal men used cattle work to regain or maintain their pride as men, in a colonial context. Their use of this work to continue ritual ties with land challenged colonial ownership and the domination of white Australia culture' (McGrath 1987: 46).

The seasonal cycles and the nature of cattle work involved a mobile existence not entirely alien to traditional land use patterns and Aboriginal stockmen, in particular, were able to maintain a greater degree of continuity with their culture than their counterparts living in towns or on missions. They supplemented their diet with bush food and sustained a fragmented relationship with their country until the wet season. The routine of station life dictated that no rations were supplied during the wet season and for about three months of the year the people were free to leave the station.

This was an important period in the annual calendar and was a significant factor in the ability of Aboriginal people to maintain a high degree of cultural continuity (Micha pers. comm.). Pastoralists had imposed restrictions on the type of ceremonies which could be performed and had prohibited all initiation ceremonies (K Akerman pers. comm.). The wet season became the period in which people were free to visit the sites within their traditional country with less fear of being shot; they visited relations and held rituals and ceremonies. They also returned to a largely hunting and gathering lifestyle. This afforded opporturities to pass on to their children skills and knowledge at many levels, as hunting and gathering was also an expression of spiritual attachment to land with many complex meanings (Young and Doohan 1989: 132). 
Although past ownership of land did not endow the Aboriginal people with any legal rights within Western law, they continued to recognise and practice such rights and made a distinction between land-users and land owners:

They drew a contract, in these terms between a local descent group having primary spiritual rights in land (recognising that other secondary rights were important too), and a mixed group which economically exploited land. Europeans and their interests were seen as falling into the second category. The difference was that Europeans exploited the land without providing any real compensation for its usage and without allowing equal participation on the part of Aborigines. Aborigines accepted what was offered to them, in the way of food and goods, as no more than their due - as payment, however inadequate, for use and occupancy. Possession of the land however, in Aboriginal belief, remained in their hands because each Aboriginal person was closely linked to that land - to specific stretches of land; and the land, in their view, was inalienable' (Berndt and Berndt 1987: 279).

This continuity of land ownership and thus of traditional religious beliefs and practices provided a necessary and continuing emotional security and a counterbalance to the disruption of their socioeconomic security (Berndt and Berndt 1987: 274).

By the late 1920s the ration and an annual replacement of clothes was the accepted rate of pay to Aboriginal 'stockboys' ${ }^{8}$ and the Aboriginal camp became a labour pool for additional labour. A new culture had emerged on the stations, based around a stable Aboriginal population. The pastoralists' need for a cheap labour force which could be controlled had been satisfied. As this relatively stable system of labour, and increasing profits, emerged during the first quarter of the twentieth century, many of the familyowned and controlled stations were sold to investment companies, absentee landlords concerned only with economic viability and with no concern for the traditional owners. Soon after World War I new poliçies were being implemented and a new era in pastoral management began.

It is apparent from these documented histories that, for most of the traditional owners, the transition from a traditional hunting and gathering lifestyle to the station camps had been made by the 1920s. This transition is arguably the most significant of several social and demographic transitions which occurred in this region during the first one hundred years following the European invasion. Most Aboriginal people lived for 9-10 months of the year at the station camps and those who were able to work were incorporated into the hierarchical structure of the pastoral industry and worked in return for rations. Despite this they were able to maintain a high degree of cultural continuity and continue religious and social relationships which were able to be reinforced during the wet season. Whilst the pastoralists were later to claim that they supported a large and dependent Aboriginal population, the Aboriginal people perceived themselves as sharing their country with the pastoralists and their cattle, whilst adapting their culture to the changing circumstances.

8. No historical reference was found to Aboriginal stockmen. The term 'stockboy' when referring to Aboriginal employees seems to have been consistently used on all cattle stations in this region at this time. 


\section{0-1970s: legislation, rations and the transition to wages}

The frontier period of invasion and colonisation was followed by a period when the mode of production on the Kimberley pastoral leases developed an annual routine and a degree of economic security. New homesteads were built, cattle markets were secure although fluctuating, permanent roads and regular services were established, and the practice of using Aboriginal labour in return for rations became well established. This is illustrated by Terry's description in 1927 of the new homestead at Gordon Downs which had replaced the original cottage since his visit two years earlier:

It was interesting to see the place where our fuel supplies had been dumped at this homestead. At my previous visit, the holy-of-holies the manager's house had been a small humpy consisting of four stone walls capped by a tin roof. Now there is a double-storey house built on piles, palatial in comparison and the place that had once housed the lord of all he surveyed was become a roofless shack, wherein were stacked rows of red benzine drums and debris. What a change wrought by fate and progress in such a short space of time (Terry 1927:161).

Whilst the pastoralists prospered during this 'golden era', little changed for the Aboriginal people living in the station camps until after World War II. Government policies gradually reflected the growing public recognition that the beliefs Iabelled Social Darwinism (Mulvaney 1985: 68-9) were unjust. A new era of government policies was put into place. These were founded in the belief that opportunities for Aboriginal people would emerge if they were assimilated into the lowest rung of the wider white Australian society. The following statement by a government Minister in 1945 encapsulates the dominant white attitudes to Aboriginal people which prevailed during the 1930s, 1940 s and into the 1950s.

Under existing policy aboriginals employed on cattle stations are not paid any wages, but are clothed and fed by the employers. In addition, the employers have to maintain the whole of the dependents of the aboriginal employees. It is stated that the cost of the maintenance of the dependants more than offsets the expenditure that would be involved by paying the employees wages and leaving them to maintain their dependants. On the larger cattle stations there are considerable numbers of aboriginals, the majority of them ... seemed to be happy and in good condition. The aboriginal employees like their work and are a definite asset to the stations (Minister for the Interior, November 1945, quoted in Berndt and Berndt 1987: 51).

Berndt and Berndt provide a different perspective:

They owned neither the huts in which they lived nor the land on which these were built, they had no rights of tenure, and in some cases have been sold or transferred with the property. Their security depended on the new land holders - a precarious security at times and in places where there were few, if any, checks or curbs on the treatment accorded these people who had, for a long period, no effective rights at law (Berndt and Berndt 1987: 273).

\section{Summary of major legislative changes, 1930s-1970s}

A brief resume of Federal and Western Australian state legislation and regulations controlling Aboriginal people working on stations in Western Australia between 1945 and the 1970s is provided in Table 2 in order to explain how the wider political milieu continued to control their lives. This was also a period when all people living on stations 
Table 2 Govemment legislation relevant to Aboriginal people in the Kimberley, 1944-72

\begin{tabular}{|c|c|c|}
\hline Date & Name & Discussion \\
\hline $\begin{array}{l}1944 \\
\text { amended } \\
1951,1958 \\
1964\end{array}$ & $\begin{array}{l}\text { Natives (Citizens Rights) } \\
\text { Act }\end{array}$ & $\begin{array}{l}\text { Provided citizenship rights to successful applicants } \\
\text { with strict conditions. }\end{array}$ \\
\hline 1948 & Bateman Report & $\begin{array}{l}\text { Recommended major restructuring of Native Wel- } \\
\text { fare Department into districts with flow-on effect on } \\
\text { legislative changes. }\end{array}$ \\
\hline 1954 & $\begin{array}{l}\text { Native Welfare Act (1954) } \\
\text { and Native Administration } \\
\text { Act (1905-1947) amend- } \\
\text { ment }\end{array}$ & $\begin{array}{l}\text { Repeal of most of the restrictive and discriminatory } \\
\text { sections of the original act, introduced major } \\
\text { reforms. }\end{array}$ \\
\hline 1960 & $\begin{array}{l}\text { Commonwealth Social } \\
\text { Services (Consolidation) } \\
\text { Act amendment }\end{array}$ & $\begin{array}{l}\text { Restrictions on Aborigines receiving pensions and } \\
\text { maternity allowances were lifted. }\end{array}$ \\
\hline 1961 & $\begin{array}{l}\text { Commonwealth Select } \\
\text { Committee }\end{array}$ & $\begin{array}{l}\text { Inquired into whether Commonwealth franchise } \\
\text { should be extend to Aborigines - they were } \\
\text { granted the right to enrol. }\end{array}$ \\
\hline 1963 & Native Welfare Act & $\begin{array}{l}\text { Replaced Native Administration Act. A number of } \\
\text { other legislative amendments also occurred in } 1963 \text {, } \\
\text { for example, Criminal Code, Evidence Act, Mining } \\
\text { Act, Licensing Act, Firearms and guns Act, Health } \\
\text { Act etc. }\end{array}$ \\
\hline 1963 & Criminal Code amended & $\begin{array}{l}\text { Abolished special provisions relating to the whip- } \\
\text { ping of 'natives'. }\end{array}$ \\
\hline 1967 & Federal Referendum & $\begin{array}{l}\text { Australians voted 'yes' to citizenship rights for } \\
\text { Aboriginal people. }\end{array}$ \\
\hline 1968 & $\begin{array}{l}\text { Pastoral Industry Award } \\
\text { (1965) amended }\end{array}$ & $\begin{array}{l}\text { Equal wages paid to Aboriginal people in the pasto- } \\
\text { ral industry. }\end{array}$ \\
\hline 1971 & Liquor Act amendment & $\begin{array}{l}\text { Last two restricted areas in WA, the Kimberley and } \\
\text { Goldfields, were de-proclaimed. }\end{array}$ \\
\hline 1971 & $\begin{array}{l}\text { Repeal of the Aboriginal } \\
\text { (Citizens Rights) Act, WA. }\end{array}$ & $\begin{array}{l}\text { Legally opening the way for full political, economic } \\
\text { and social involvement as Australian citizens. }\end{array}$ \\
\hline 1972 & $\begin{array}{l}\text { Aboriginal Affairs Plan- } \\
\text { ning Authority Act }\end{array}$ & $\begin{array}{l}\text { Repealed the Native Welfare Act, 1963. Policy now } \\
\text { one of self-determination. }\end{array}$ \\
\hline
\end{tabular}

were becoming aware of social changes and when much of the earlier repressive legislation was repealed.

The Native Administration Act of 1905-47 had emphasised the inferior status of Aboriginal people more than any other legislation in Western Australia. An attempt to alleviate this situation was made through the Natives (Citizenship Rights) Act (1944). This Act provided for the issue by a Magistrate of a certificate of Citizenship Rights to a suc- 
cessful adult applicant who was 'deemed to be no longer a native for the purpose of the Native Administration Act, or any other Act, but such a person was also forbidden to associate with other Aborigines, even members of his/her family. This Act was amended in 1951, 1958 and 1964. The underlying principle, however, remained the same: 'One could be Aboriginal or a citizen, but not both' (McLarty 1965).

In 1954 the Native Administration Act was substantially amended to remove most discriminatory and restrictive sections and the remaining provisions were removed by the Native Welfare Act, 1963. Under this Act the Native Welfare Department was again substantially reviewed and there was a shift from an assimilationist policy toward one which recognised self-determination. This Act was in place for a few significant years during which Aboriginal people were granted equal wages and full citizenship rights. It was replaced by the Aboriginal Affairs Planning Authority Act, 1972.

The policy of not permitting Aboriginal people to move from their stations was in place until the 1950s. Jack Bohemia, a police tracker working in the Fitzroy Valley during the 1940s and 1950s, described in detail the treatment of Aborigines who left the stations where they were employed (Bohemia and McGregor 1995). It is clear from his accounts that activities on behalf of station owners occupied a great deal of police time. All Aboriginal people continued to be accounted for; those reported to police as being absent from their allocated station (except to attend urgent family business such as funerals) were hunted and returned, usually in chains. New arrivals from the deserts were allocated stations, most frequently those where they arrived, or were escorted to stations where the owners had indicated that they were short of labour. These restrictions were confirmed by Micha (1961:71) as being enforced at least until the end of the 1950s. From the 1920s to the 1950s the number of able-bodied Aboriginal 'workers' was regarded as an asset of the property, able to be transferred to a new owner when a pastoral lease was sold.

\section{Wages and rations}

Before the 1950s, Aboriginal employees on stations were paid only with rations. In 1948, following a protracted wages strike led by Don McLeod in the Pilbara in 1946, an inquiry into Aboriginal working conditions found that the Kimberley was the only region in Australia not paying any wages to Aboriginal employees. A further inquiry in 1949 by the Department of Native Welfare recommended the immediate introduction of a cash wage and the provision of a minimum standard of housing. This recommendation was disputed by the Pastoralists' Association. The minutes of a meeting between representatives of the Pastoralists' Association and the Commissioner for Native Affairs held at Pastoral House, Perth on 7 February 1949 record that:

Mr Durack pointed out the complications of the non-payment of wages to natives in the Kimberley and mentioned that in the Territory natives were being paid wages and he was of the opinion that similar action would have to be contemplated in Western Australia. He was very firm in his statement that the Department should lay down a set standard of wages payable to natives be it $5 /-$ or $25 /-$. Pastoralists Association and Commissioner for Native Affairs: 1949: 4

At a later meeting of the Pastoralists Association of Western Australia in 1950 it was resolved to agree to pay a wage to Aboriginal 'workers' on cattle stations in the Kimberley. This was $£ 1$ per month for stockmen and 10/- per month for domestics 
(Hawke and Gallagher 1989: 68-9); from this their weekly ration of food was deducted. In addition, some individual employers paid a bonus, particularly after a good year, and some paid long service leave. ${ }^{9}$ This agreement, and one subsequent wage rise, determined all that Aboriginal employees received until the introduction of full award wages on 1 December 1968. Before 1961 an allowance was made to stations for the support of 'dependent' Aborigines (unemployed, children and pensioners) through the office of the Protector of Aborigines. Between 1961 and 1970 some social security payments were received by the stations on behalf of unemployed Aboriginal people. It was not until after 1970 (in WA) that those who were unemployed became entitled to full unemployment benefits, pensions or social security payments. Pensions and social security payments were made directly into an account maintained by the pastoral company on behalf of individuals and the resident book keeper was responsible for ensuring that rations provided through the station store were deducted from the appropriate account before the benefit was paid.

Rations were only available from the station to which the Aborigine 'belonged' and, according to Micha (1961: 71) it was the provision of rations which made it possible for pastoralists to maintain an assured labour force. He described the distribution of tea, flour, tobacco, clothes and sugar to the people living at Gordon Downs Station in 1959-60, and recorded that the distribution of rations had been used to develop a dependence on the pastoralists (Micha 1961: 67).

The Protector of Aborigines had paid stations a small subsidy for each ration provided but this ceased when Aboriginal people became eligible to receive some welfare benefits. In order to administer the payment of the pensions the Department of Social Security classified cattle stations on which Aboriginal pensioners were resident as 'institutions'. For this reason full pensions were not received by pensioners but paid directly into the general account of the station on which they were resident. It was noted by the Superintendent of the Native Welfare Department, Derby, that this itemised issue (dated 23 March 1965) represents the full value of the pension. According to Stevens (1974: 157) the legality of this was questionable. The amounts of cash received by the pensioners after their expenses had been deducted varied widely between stations.

Although recommendations were made by the Department regarding the quantity and quality of the rations to be provided to Aboriginal workers both of these varied widely according to the policies of the station owners and the goodwill of individual station managers. The report of Berndt and Berndt (1987: 63) on their fieldwork on several stations owned by the Australian Investment Agency confirmed that the overstating the rations provided was practised by station managers in 1946.

The returns regarding Aborigines forwarded to the Department of Native Affairs and to the head office of the AIA, follow a pattern set down by the AIA ... However, certain discrepancies are evident, not only in the figures as presented and arranged, but also in the general impressions produced ... apart from the inequality in the value of the

9. Currency is expressed here as pounds ( $€$ ), shillings (s) and pence (d). For example, 10/- was ten shillings and $£ 1 / 11 / 4$ was one pound, eleven shillings and 4 pence. There are 12 pence in a shilling and 20 shillings in a pound. At the time decimal currency was introduced (14 February 1966) one Australian pound was equal to two Australian dollars. 
food as actually obtained and as therein represented to have been obtained. (This information was supported by detailed observation over a period, in addition to data obtained from both Aboriginal and non-Aboriginal sources.) That is, perusal of these records alone, without other evidence, would result in the inference being drawn that the cost of maintaining Aborigines attached to the station was higher than that of maintaining non-Aboriginal employees, whereas this was not the case. This is clearly shown in the 'Working Records' of the station.

In 1951 the Commonwealth Department of Health conducted an Australia-wide nutrition survey of the Aboriginal population (Commonwealth Department of Health 1952). The results of that survey are presented in Table 3, which provides diet records for eight Kimberley cattle stations, missions, Aboriginal families living in towns and hospitals. In addition the Department of Native Affairs ration allowances in 1951 and 1952 are included for comparison with the ration actually provided. The nutrient compositions of this dietary information have been evaluated by Smith and Smith (1999). Several conclusions can be drawn about the diet of Aboriginal people living on stations at this time, based on this evaluation and on Table 3 (col. 1):

- The station diet consisted essentially of flour, meat and sugar and was very inadequate in fresh fruit and vegetables, milk, cheese and butter.

- The station diet supplied adequate protein energy, iron and some minor dietary components.

- Shortfalls in foods containing vitamin $A$, calcium and vitamin $C$ would have led to serious dietary deficiencies.

- Shortfalls observed in the station and mission diet were corrected in the hospital diet (col. 3) and to a large extent in the self-selected diet of Aboriginal households living near large towns (col. 2). ${ }^{10}$

The 1951 nutrition survey did not include bush foods which were recorded as being used in most of the station camps. ${ }^{11}$

The 1951 nutrition survey also revealed that Aboriginal people receiving rations at one south Kimberley station had the lowest calorie intake per head per day of all eight Kimberley stations in the study and that this was $50 \%$ less than the next lowest figure (Commonwealth Department of Health 1952). In reference to this same station, a nurse who had worked at the Fitzroy Crossing Hospital in the early 1960s said:

A main problem was ... station - it was their kids we were sitting up nursing at night and watching die. It had a very bad history. The diet on _ was bread and tea, three times a day. This was the ration. So the women would go up and get a hunk of bread and a billy of tea and some meat when a killer came in. The best cuts went to the top house, then the next best to the manager and then further down - it would be the hooves and the horns and the gut and entrails and stuff like that which would be brought up into the camp and boughs and leaves would

10. This point is emphasised because it was widely believed by Western health providers at that time, and until quite recently, that poor nutrition in Aboriginal communities was an outcome of their own poor food choices.

11. In the wider study from which this paper is derived (Smith 2000) it was found that although bush foods were used and valued, the people living in the camps were unable to exploit local bush foods in sufficient quantities to be nutritionally significant. 





be got and this stuff dropped into the middle of it and the women would rush out and the dogs would rush out - it was appalling.

(Interview 9).

There were also many stations which did supply adequate rations. This was supported by anecdotal evidence, an example of which is the following statement, which also supports the evidence that Aboriginal people supplemented their diet with traditional foods on a regular basis:

The people on __ were well looked after, had a better diet than the other stations too - river people, always had access to fresh food, went fishing and hunting ... There was a big vegetable garden too.

Interview 8 [refers to the 1960s and early 1970s]

Detailed recommendations regarding rations based on the 1951 nutrition survey (WA Archives, Account 993/Item 101/51/1-5) were sent to all stations by the Department of Native Affairs (Department of Native Affairs 1952a,b). Included were the recommended daily food allowances for Aboriginal 'workers' which were circulated to station managers (Table 4).

Table 4. Basic ration scale per head - recommendations, 1952

\begin{tabular}{l|ll}
\hline Item & Per day & Per week \\
Meat (boneless wgt) & $1 \mathrm{lb}$ & $7 \mathrm{lb}$ \\
Potatoes & $4.5 \mathrm{oz}$ & $2 \mathrm{lb}$ \\
Vegetables or fruit, fresh or tinned & $4.5 \mathrm{oz}$ & $2 \mathrm{lb}$ \\
Dried peas & $1 \mathrm{oz}$ & $.5 \mathrm{lb}$ \\
Bread or flour & $12 \mathrm{oz}$ & $5 \mathrm{lb}$ \\
Baking powder & $.5 \mathrm{oz}$ & $3 \mathrm{oz}$ \\
Porridge meal & $2 \mathrm{oz}$ & $1 \mathrm{lb}$ \\
Sugar & $3 \mathrm{oz}$ & $1.25 \mathrm{lb}$ \\
Jam, Syrup or treacle & $3 \mathrm{oz}$ & $.75 \mathrm{lb}$ \\
Dried milk or cheese & $.5 \mathrm{oz}$ & $4 \mathrm{oz}$ \\
Liver or & $1 \mathrm{oz}$ & $7 \mathrm{oz}$ \\
green vegetables & $4 \mathrm{oz}$ & $1.75 \mathrm{lb}$ \\
Dripping margarine or butter & $1 \mathrm{oz}$ & $.5 \mathrm{lb}$ \\
Salt & & $1 \mathrm{oz}$ \\
Tea & & $3 \mathrm{oz}$ \\
Water-pure potable water from an approved & $6 \mathrm{pints}$ & $5 \mathrm{qts}$ (sic) \\
source and entirely available for drinking & \multicolumn{2}{|l}{$(=5 \mathrm{gal}$.) } \\
\hline Note: $1 \mathrm{lb}=\sim 0.45 \mathrm{~kg} ; 1 \mathrm{oz}=-28 \mathrm{~g} ; 1$ pint $=-0.57 \mathrm{litres}$ \\
Reproduced from Department of Native Affairs, Western Australia $1952 \mathrm{~b}: 4$. \\
\hline
\end{tabular}


It is clear from both the 1951 nutrition survey report and from these recommendations that cultural assimilation was a further goal which, it was anticipated, would evolve through a 'gradual transition from foods and methods of cooking at present accepted by Aboriginals to those of white Australians' (Department of Native Affairs, Western Australia 1952b: 4).

Although comparative Kimberley data are not available, Stevens (1974) provides sufficient information about rations on cattle stations in the Northern Territory in the 1960s to enable some assessment of changes in the ration system. Both the Kimberley and the Northern Territory were bound by the Commonwealth Conciliation and Arbitration Commission awards enforced by the Native Welfare Branch in each region, and the Commonwealth nutrition survey 1951 was also conducted on stations in the Northern Territory with the same or very similar results as the Kimberley region.

\section{Table 5. Weekly ration per person for all residents on one Northern Territory station (152 persons) in 1965}

\begin{tabular}{l|l}
\hline Item & Quantity \\
Flour and flour/ cereal prod- & \\
ucts & $4.73 \mathrm{lb}$ \\
Milk, powdered & 0.01 pints \\
Meat, fresh & $7.0 \mathrm{lb}$ \\
Dried fruits & $0.03 \mathrm{lb}$ \\
Sugar - incl. treacle, golden & \\
syrup \& jam & $0.48 \mathrm{lb}$ \\
\hline Data derived from Table 7 in Stevens 1974: 85. \\
\hline
\end{tabular}

In Table 5 data derived from Stevens (1974: 85) have been converted into a form which allows comparisons to be made with Tables 3 and 4 . These comparisons reveal that the revised dietary criteria laid down by the Department of Native Welfare in 1952 - as a result of the 1951 Commonwealth Department of Health survey - was not put into practice at all, and not effectively supervised by the Department of Native Welfare. They also suggest that there were no perceptible improvements in the quantities of food available or in the variety of food available to employees on stations in the Kimberley and adjacent Northern Territory in the twenty years between 1950 and 1970.

Table 6 shows a deficit in expenditure in 1965 by a Northern Territory cattle station on maintenance cost of Aboriginal employees and dependents, including diet, when compared with estimates of the Aboriginal Welfare Branch (Stevens 1974: 91). In this example the net annual expenditure is $£ 4145$ and the net annual expected expenditure estimated by the Welfare Branch (NT) is $£ 13060$. These figures are supported by data from other cattle stations used in the same reference in which Stevens estimates deficits in rations of between $30 \%$ and $85 \%$. 
Table 6. Aboriginal wages and sustenance costs, 1965 and Welfare Branch (NT) estimates of station costs for maintaining Aboriginal labour force

\begin{tabular}{|c|c|c|c|c|c|}
\hline \multirow{3}{*}{$\begin{array}{l}\text { Expenditure } \\
\text { categories }\end{array}$} & \multicolumn{3}{|c|}{$\begin{array}{l}\text { Station costs for maintaining an Aboriginal } \\
\text { labour force }\end{array}$} & \multicolumn{2}{|c|}{$\begin{array}{l}\text { Welfare Branch (NT) esti- } \\
\text { mates of maintaining an } \\
\text { Aboriginal labour force }\end{array}$} \\
\hline & $\begin{array}{l}\text { Pensioners } \\
\text { (12) weekly }\end{array}$ & $\begin{array}{l}\text { Stockmen } \\
\text { (22) weekly }\end{array}$ & $\begin{array}{l}\text { Whole of camp } \\
\text { (70 persons) } \\
\text { annually }\end{array}$ & $\begin{array}{l}\text { Single } \\
\text { stockman }\end{array}$ & $\begin{array}{l}\text { Whole of camp } \\
\text { ( } 70 \text { persons) } \\
\text { annually }\end{array}$ \\
\hline & f s. d. & f s. d. & f s. d. & $£$ s. d. & fs.d. \\
\hline Allowance & 100 & 224 & 383500 & 283 & \\
\hline Food & 105 & 105 & 169600 & 3350 & \\
\hline Meat & 1111 & 1111 & 99800 & \} & \\
\hline Clothing & 94 & 94 & 79900 & 150 & \\
\hline Tobacco & 410 & 410 & 40300 & & \\
\hline $\begin{array}{l}\text { Soap and } \\
\text { matches }\end{array}$ & 11 & 11 & 15800 & & \\
\hline $\begin{array}{l}\text { GROSS } \\
\text { COST }\end{array}$ & 2177 & 4911 & 788900 & 683 & 1306004 \\
\hline $\begin{array}{l}\text { Less pension } \\
\text { funds }\end{array}$ & 600 & 96 & 374400 & & \\
\hline $\begin{array}{l}\text { NET COST to } \\
\text { station }\end{array}$ & 325 & 405 & 414500 & 683 & 1306004 \\
\hline
\end{tabular}

Since most Aboriginal people employed on stations had received some form of wages since 1950 (although often only in the form of a store credit) and the white employees were paid full wages regularly, the store was the place where surplus money could be spent on additional food, clothing and other goods. It was also where the rations were dispensed. Those who received the ration, however, seldom received any surplus from their pensions to spend in the store. Furthermore, Stevens (1974: 156) noted that at some station stores the Aborigines were not informed of the prices of the commodities that they received. In these cases

The employee simply asked for goods, and if his account was in credit, he was handed them without reference to the price. A sum was then deducted from the employee's account.

Paradoxically, rations were also the subject of constant documentation and scrutiny, not with reference to their quality and quantity but the amount they cost the government. Correspondence concerning the hospitalisation of two Christmas Creek Station stockmen in Derby in 1968 illustrates this. The first letter is an account for $\$ 9.18$ sent to the manager of Christmas Creek Station for the supply of rations by the Department of Native Welfare in 1968 to two Aborigines in Derby for medical treatment (WA Archives, Consignment 1733 Item 196/44/3); the second letter is from the Commissioner of Native Welfare's office in Perth to the superintendent in the Derby office inquiring why the account had been sent (WA Archives, Consignment 1733 Item 1196/ 
44/4). Whenever Aborigines left their station and were supplied with rations elsewhere by the government, meticulous records were kept and the station asked to refund the cost. WA Archives consignment 1733 Item 196/44/5 is an example of the standard form used as a receipt for payment of a ration order - in this case it was issued to Jubilee Downs for an amount of $£ 2 / 0 / 6$. A further document, WA Archives consignment 1733 Item 196/44, is a record sheet from the Halls Creek office of the Department of Native Welfare, dated 25 November 1960, naming individuals in receipt of rations during the previous quarter. This detailed recording of all travel by Aborigines is an example of the net of surveillance used by police, bureaucrats and pastoralists to control their lives.

The Department of Native Affairs, through its patrol officers, was responsible for the surveillance of the living conditions in the station and for ensuring that the Aboriginal Ordinance regulations were observed and station owners employed bookkeepers who were responsible for completing Aboriginal employment returns for this Department twice a year. A now retired station manager reported that the bookkeepers employed by the larger pastoral companies were so thorough that the 'only way a manager back then could make a little on the side for himself was through the rations and the store' (Interview 7).

The Australian Aboriginal population did not have rights to full citizenship unless people had been granted one of several forms of legal exemption (Berndt and Berndt 1979). They were excluded from the jurisdiction of the Commonwealth Arbitration Court and, in a society so concerned with industrial justice, the question of paying Aboriginal employees wages for their substantial contribution to the Kimberley cattle industry was seldom addressed (Stevens 1974: 189-205; Marshall 1989). Stevens (1974: 189-205) detailed the events which led to the judgement by the Full Bench of the Commonwealth Conciliation and Arbitration Commission, 1965. This judgement stated that by 1 December 1968 all male employees of cattle stations in the Northern Territory were to be employed subject to the awards and determination of the Commission - with a provision for 'slow workers'.$^{12}$ In an Australia-wide referendum held in 1967 the nonAboriginal population of Australia was asked to decide whether Aboriginal people should be granted full citizenship rights. The result was a resounding 'yes' vote. A consequence of this referendum was the extension of the 1965 ruling of the Conciliation and Arbitration Commission to include all Aboriginal employees in the pastoral industry in all states and the payment of the standard Pastoral Award from 1 December 1968.

Following the passing of the Pastoral Award in Western Australia (almost three years later in 1971) many station owners within the Kimberley region, appear to have decided with a single mind that the time had come for the Aboriginal people living on the stations who were not employees to be removed. They did not, however, expect that many of the employed labour force whose loyalties were to their families, would move as well. At this time many pastoralists found they lost both their access to cheap labour and their most experienced stockmen. For most of these Aboriginal people, the 'station times' ended in the 1970 s and the struggle for land rights commenced.

12. The Australian Workers Union spent $\$ 28$ per head in the Northern Territory to get the Aboriginal station workers signed up as unionists; they could not afford to then come to the Kimberley (interview 29). 


\section{Concluding comments}

What are now referred to by Aboriginal people in the Kimberley region as the 'station times' lasted for seventy to eighty years and was a time when most Aboriginal people learnt to share their traditional country with the pastoralists. It is also a time that many now reflect on with considerable nostalgia. This paper has sought to describe some methods used by some pioneering pastoralists to control the Aboriginal population and to ensure a constant and cheap labour force on the cattle stations from colonisation in the 1880 s until the 1970s. The region is remote. It is likely that few of the early pastoralists would have been literate, and none of the Aboriginal people were literate. As a consequence sources of information, particularly about the period before the 1920 s, were difficult to locate.

From the information presented, the frontier period (1880s to the 1920s) in the Kimberley region was a particularly violent period, the land was occupied by cattle and the young and fit members of the Aboriginal population were pressed into forming a free labour force, although they were never referred to as slaves. In addition, the pastoralists were able to ensure the control and surveillance of the Aboriginal population by influencing state legislation. At first the legislation was repressive, whilst attempting to be humane. The extent to which this legislation changed through the twentieth century also reflected the changing attitudes of the wider society. Ironically, it was the achievement of full citizenship and the 1968 Pastoral Industry Award, giving Aboriginal people the right to equal wages, which resulted in the final act of their dispossession.

Rations are shown to have been central to labour relations on cattle stations. Until the 1960s they were the only payment made to Aboriginal 'workers'. Although there were station owners and managers who did provide sufficient rations for their Aboriginal employees, it is easy to understand how the Aboriginal people were able to be exploited. For all of the period discussed, most were illiterate and had never attended school, and few had any experience of handling cash. By the 1960 s most knew that they received a wage or a pension, but their food and any money they received always came directly from the station manager and, despite the availability of some cash, it was the ration which remained the recognised remuneration for Aboriginal labour in the Kimberley region until the introduction of equal wages in $1971 .^{13}$

\section{Acknowledgements}

Oral histories were recorded as part of a wider project and the memories of senior members of the Jaru people have contributed to deeper understandings about the colonisation of this region. The field research associated with this study was undertaken with the cooperation of the Aboriginal people living at Kundat Djaru community and with support from Flinders University, Adelaide. I wish to thank those who read and commented on drafts of this paper, including Associate Professor Donald Pate, Kim Doohan, Daniel Vachon, Joe Blythe and Matthew Wrigley. This paper is part a PhD research project with the Department of Archaeology, Flinders University, South Australia.

13. Despite the payment of award wages, full citizenship rights, including the right to vote, continued to be withheld from Aboriginal people in the Kalgoorlie and Kimberley regions until 1971. 


\section{References}

Aboriginal Affairs Planning Authority, 1994. Regional Planning Authority. WA's Aboriginal People. Perth.

Andrews, D, 1996. 'Ai gon fo gud', in Kimberley Language Resource Centre and authors Moola Bulla: in the shadow of the mountain. Broome.

Bell, D, 1983. Daughters of the Dreaming. Melbourne.

Berndt, RM and Berndt, $\mathrm{CH}$ (eds), 1979. Aborigines of the West. Nedlands.

Berndt, RM and Berndt, $\mathrm{CH}, 1987$. End of an era: Aboriginal labour in the Northern Territory. Canberra.

Bohemia, J and McGregor, W, 1995. Nyibayarri. Kimberley Tracker. Canberra.

Bolton, GC, 1958. Alexander Forrest, his life and times. Melbourne.

Cane, SB,1990. 'Desert demography: a case study of pre-contact Aboriginal densities in the Western Desert of Australia', in Meehan, B and White, N (eds) Hunter-gatherer demography, past and present. Oceania monograph no. 39.

Clement, C, 1987a. Pre-settlement intrusion into the East Kimberley. East Kimberley Impact Assessment Project, Working Paper no. 24, Centre for Resource and Environmental Studies, ANU, Canberra.

Clement, C, 1987b. Historical notes relevant to impact stories of the East Kimberley. East Kimberley Impact Assessment Project, Working Paper no. 29, Centre for Resource and Environmental Studies, ANU, Canberra.

Commonwealth Department of Health, 1952. Dietary survey of Aboriginals in Western Australia, 1951. Canberra.

Department of Native Affairs, Western Australia, 1952a. Memo, ref: DRB/LA, 18 March 1952. Re: Nutrition Survey. Perth.

Department of Native Affairs, Western Australia, 1952b. Circular Instruction 39. To all Missions, Departmental Institutions and Field Officers, 4th September, 1952. Ration Scales. Perth.

Durack, M, 1967. Kings in grass castles. Sydney.

Hawke, S and Gallagher, M, 1989. Noonkanbah. Fremantle.

James, HC, 1979. Western Australia: a pictorial parade of 150 years. Adelaide.

Kolig, E, 1987. The Noonkanbah story. Dunedin.

Marshall, P, 1989. Raparapa Kularr Marrtuwarra: stories of the Fitzroy Valley_drovers. Broome.

McGrath, A, 1987. 'Born in the cattle': Aborigines in cattle country. Sydney.

McLarty, BA, 1965. Native Welfare in Western Australia. WA Archives accession no.1733/ 493, Department of Native Welfare files. Perth.

McPherson, PD, 1995. 'Pioneering itinerant nursing in the Kimberley.' Paper presented at the Royal College of Nursing Conference on Nursing History, Canberra, 23 September 1995.

Micha, FJ, 1961. 'Eingeborene als arbeitskrafte auf den viehstationen der sudostlichen Kimberley, vornehmlich auf Gordon Downs station.' Herman Trimborn zum 60. Geburtstag. Braunschweig, pp 65-93. 
Mulvaney, DJ, 1985. 'The Darwinian perspective', in Donaldson, I and Donaldson, T (eds) Seeing the first Australians. Sydney, pp 68-75.

Pastoral Association and the Commissioner for Native Affairs, 1949. Minutes of a conference between representatives of the pastoral association and the Commissioner for Native Affairs, held at Pastoral House, 7 Feb 1949. (WA State Archives Accession no. 1667/ item no. 4627).

Ross, $\mathrm{H}, 1987$. Just for living. Canberra.

Ross, $\mathrm{H}$ and Bray, E, 1989. Impact stories of the East Kimberley. East Kimberley Impact Assessment Project, Working Paper no. 28, April 1989. Canberra.

Rowse, T, 1998. White flour, white power: from rations to citizenship in central Australia. Cambridge.

Royal Commission, State of Western Australia, 1905. Report of the Royal Commission on the Condition of Natives by Commissioner W.E. Roth. Perth.

Royal Commission, State of Western Australia, 1974. Report of the Royal Commission upon all matters affecting the well being of persons of Aboriginal descent in Western Australia. Perth.

Saggers, S and Gray, D, 1991. Aboriginal health and society. Sydney.

Smith, PA, this issue. 'Into the Kimberley: The invasion of the Sturt Creek Basin (Kimberley region, Western Australia) and evidence of Aboriginal resistance.' Aboriginal History 24.

Smith, PA, 2000. 'Station camps: the ethnoarchaeology of cultural change in the postinvasion period in the south Kimberley, Western Australia.' Unpublished PhD thesis, Department of Archaeology, Finders University, South Australia.

Smith, PA and Smith, RM, 1999. 'Diets in transition: hunter-gatherer to station diet and station diet to the self-select store diet.' Human Ecology 27(1): 117-34.

Stevens, F, 1974. Aborigines in the Northern Territory cattle industry. Canberra.

Taylor, P (ed.), 1988. After 200 years: photographic essays of Aboriginal and Islander Australia today. Canberra.

Terry, M, 1925. Across unknown Australia: a thrilling account of exploration in the Northern Territory of Australia. London.

Terry, M, 1927. Through a land of promise. London.

Young, E and Doohan, K, 1989. Mobility for survival: a process analysis of Aboriginal population movement in central Australia. ANU North Australia Research Unit Monograph. Darwin.

\section{Unpublished}

WA Archives documents:

Consignment 1733 Item 196/44/3

Consignment 1733 Item 1196/44/4

Consignment 1733 Item 196/44/5

Consignment 1733 Item 196/44

Account 993/Item 101/51/1-5 